\title{
МЕТОДОЛОГИЧЕСКИЕ ОСНОВЫ ПОДГОТОВКИ ОПЕЦИАЛИСТА ОБРАЗОВАНИЯ В ОБЛАСТИ БЕЗОПАСНОСТИ ЖИЗНЕДЕЯТЕЛЬНОСТИ
}

\author{
Абрамова С.В., Бояров Е.Н.
}

\begin{abstract}
ФГБОУ ВПО «Сахалинский государственный университет», г. Южно-Сахалинск, Россия (693008, 2. Южно-Сахалинск, ул. Ленина, 290) e.boyarov@mail.ru
\end{abstract}

Перспективным путем развития системы подготовки специалистов является дальнейшее развитие и укрепление отечественной высшей школы. При этом ядром комплексной системы выполнения государственного заказа российскому образованию на формирование гражданских и патриотических качеств личности и культуры безопасности у подрастающего поколения должно стать образование в области безопасности жизнедеятельности. В статье рассматриваются некоторые методологические основы подготовки специалиста образования в области безопасности жизнедеятельности. Методологическое значение для развития системы уровневого высшего профессионального педагогического образования в области безопасности жизнедеятельности имеют закономерности, основные и специфические, образования в области безопасности жизнедеятельности. Представленные в ходе исследования специфические показатели образование в области безопасности жизнедеятельности показывают его высокую и многостороннюю значимость и позволяют обеспечить практическую реализацию основополагающих принципов образования в данной научной области.

Ключевые слова: безопасность жизнедеятельности, модернизация высшего профессионального образования, закономерности образования в области безопасности жизнедеятельности, показатели образования в области безопасности жизнедеятельности.

\section{METHODOLOGICAL BASIS FOR TRAINING OF THE SPECIALISTS IN THE FIELD OF EDUCATION OF LIFE SAFETY}

\author{
Abramova S.V., Boyarov E.N.
}

\section{Sakhalin State University, Yuzhno-Sakhalinsk}

Yuzhno-Sakhalinsk, Russia (693008, Yuzhno-Sakhalinsk, Lenina st., 288) e.boyarov@mail.ru

Developing of the system for training of the specialists is a perspective way of development of the national higher school. The core of the integrated system of performance of the state order of the Russian education in the formation of civil and patriotic qualities of the personality and safety culture among the younger generation, should be educated in the area of Life Safety. In article are considered some of the methodological basis of preparation of the specialist education in the field of life safety. Methodological importance for development of the system of levels of higher professional pedagogical education in the field of life safety have regularities of main and specific education in the field of life safety. Presented in the course of the study the specific indicators of education in the field of life safety show a high and multilateral importance and allow to provide practical implementation of the fundamental principles of education in this scientific area.

Key words: life safety, modernization of higher professional education, the regularities of education in the field of education of life safety, indicators of education in the field of education of life safety.

В настоящее время в условиях коренных изменений, происходящих в сфере науки, техники и производстве, российское общество идет по пути реформ, направленных на глубокие преобразования всех государственных структур. Реформирование носит 
системный характер и представляет собой комплекс взаимосвязанных политических, организационных, научно-технических, социально-правовых и экономических мероприятий, направленных на качественное преобразование государственных институтов с учетом перспектив развития общества [3].

Постоянное расширение сферы образовательных услуг, все ускоряющийся процесс морального старения всех компонентов социального опыта требуют от современного специалиста в области высшего профессионального образования высокой мобильности в сфере познания, обучения, развития и воспитания, субъективной готовности к непрерывному самообразованию и возможности приобретения новых специальностей, способности адаптироваться к быстро меняющейся дифференцированной и специализированной системе обучения, развития творческой активности [3]. В связи с этим закономерным и своевременным является реализация задачи органичного включения системы высшего профессионального (педагогического) образования в мировую систему образования, единства теоретической и практической, а также общеобразовательной и профессиональной подготовки специалиста.

В целом, перспективным путем развития системы подготовки специалистов является дальнейшее развитие и укрепление отечественной высшей школы, опирающееся на национальные традиции, высокий научный потенциал и многовековой опыт российской системы образования по подготовке высокопрофессиональных кадров (Г.А. Бордовский, 2002).

Результатом модернизации системы высшего профессионального педагогического образования должна стать обновленная система подготовки специалиста в области предметного образования на разных уровнях, отвечающая требованиям, предъявляемым современным обществом к педагогическим кадрам.

Согласно стратегии национальной безопасности России в социальной сфере, науке и образовании и долгосрочной стратегии развития России - Плана Путина, формирование личности, способной дать адекватный ответ на вызовы XXI века и обеспечить устойчивое дальнейшее развитие России, возможно, если приоритет в содержании образования будет и должен принадлежать фундаментальным мировоззренческим аспектам, раскрывающим ценностно-смысловые оценки действительности, целостное понимание явлений и процессов, происходящих в нашей стране и в мире, и направленным на повышение качества образования и патриотического воспитания молодого поколения. При этом ядром комплексной системы выполнения государственного заказа российскому образованию на формирование гражданских и патриотических качеств личности и 
культуры безопасности у подрастающего поколения должно стать образование в области безопасности жизнедеятельности.

На современном этапе развитие системы педагогического образования в области безопасности жизнедеятельности тесно взаимосвязано с определенными факторами, закономерностями и тенденциями развития общества и образования. В связи с этим, на наш взгляд, необходимо на основе теоретического анализа раскрыть некоторые методологические основы (закономерности) подготовки специалиста образования в области безопасности жизнедеятельности. Для реализации данной цели мы использовали метод теоретического анализа и синтеза научного знания и научных представлений в области высшего профессионального образования и образования в области безопасности жизнедеятельности, в частности.

Исходя из анализа опыта, накопленного высшей школой России, а также основываясь на результатах исследования работ целого ряда авторов: Ю.К. Бабанского, А.П. Беляевой, В.А. Бордовского, Г.А. Бордовского, В.А. Козырева, Н.Ф. Радионовой, И.И. Соколовой, В.П. Соломина, Н.Л. Стефановой, А.П. Тряпицыной, Н.Л. Шубиной [3], важное методологическое значение для развития системы уровневого высшего профессионального педагогического образования в области безопасности жизнедеятельности имеют, помимо основных, следующие закономерности образования в области безопасности жизнедеятельности. К таковым относятся:

1. Объективная взаимообусловленность развития теории и практики образования в области безопасности жизнедеятельности и потребностей современного общества.

Основной целью развития человечества является улучшение качества жизни на каждом этапе своего развития, что ведет к постоянному росту человеческих потребностей. Степень и качество удовлетворения этих потребностей зависят от состояния безопасности жизнедеятельности как особой научной области, педагогической науки, педагогической теории и практики и системы образования в целом. Следовательно, цели и задачи образования в области БЖД изменяются под влиянием требований социальноэкономического развития и научно-технического прогресса, особенностей социальноэкономических отношений на каждом конкретном историческом этапе развития общества.

Состояние образования во многом определяет развитие всех слагаемых государственности, материальное и духовное благополучие общества и конкретного человека [2].

В данных условиях образование в области БЖД может и должно стать ядром комплексной системы выполнения государственного заказа российскому образованию на формирование гражданских и патриотических качеств у подрастающего поколения с 
целью повышения готовности личности к восприятию современного мира опасностей, успешного применения личных и коллективных мер безопасности, совершенствования человекозащитной и природозащитной деятельности на основе развития мировоззренческой культуры безопасности, отвечающих характеру долговременной стратегии развития страны.

Таким образом, образование в области безопасности жизнедеятельности, культура безопасности человека и общества становятся необходимыми условиями перехода современной цивилизации к модели устойчивого развития [1].

2. Взаимосвязь психологической, социальной, культурологической и профессиональной сущности в личности и ее безопасной жизнедеятельности.

Развитие личности совершается в определенных социальных условиях её жизни, в деятельности, в общении с людьми. Человеческий организм развивается не только за счет энергетических ресурсов, которые поступают из внешней среды, но и вследствие взаимодействия в социальной среде. На основе отражательной способности нервной системы у личности развивается познавательное отношение к миру как отношение субъекта к объекту. Следствием указанных психофизиологических особенностей является взаимосвязь и взаимовлияние внешнего и внутреннего развития личности. Эта закономерность была впервые выявлена С. Л. Рубинштейном и получила свое дальнейшее развитие в трудах Г. С. Костюка, А. Н. Леонтьева, П. Я. Гальперина, Л. И. Божович, Т. Е. Конниковой и др. [1]. Переход внешнего (во взаимосвязи с окружающей природнотехносоциальной средой) во внутреннее (деятельностные, или профессиональнообусловленные, черты личности) касается не только процесса сознания, эта закономерность определяет и развитие отношений, которые представляют собой единство внешнего и внутреннего.

Безопасность жизнедеятельности как научная и учебная дисциплина связана с изучением закономерностей возникновения и развития угроз и опасностей и способов эффективной защиты от них социума (человека, его обществ, человечества) и окружающей его среды в любых условиях жизнедеятельности [4, 5]. В этом проявляется ее социальная направленность, поскольку объектом опасностей и угроз выступает социум, хотя субъектами могут быть и природная среда, и техногенная сфера, и информация.

Таким образом, в процессе подготовки специалистов образования в области БЖД происходит взаимообусловленное и взаимосвязанное развитие личности студента, ее социализация и совершенствование профессионализма в образовательном пространстве БЖД, что обусловливает становление духовно развитой культурной личности, обладающей целостным гуманистическим мировоззрением, активно реализующей свои 
творческие силы и способности в профессионально-педагогической деятельности, и является важным условием успешного развития всей системы образования в области безопасности жизнедеятельности на современном его этапе [1].

3. Единство интегративной целостности и комплексности высшего педагогического образования в области безопасности жизнедеятельности.

Применение идей интеграции, комплексности и синтеза наук, общей теории систем в образовании позволило выявить возможность успешной подготовки специалиста широкого профиля (учителя-предметника, преподавателя естественнонаучных дисциплин и исследователя) на базе системы генерализированных основ наук, осуществить интеграцию и дифференциацию (специализацию) образования [3].

Так, интеграция в процессе подготовки специалиста образования в области безопасности жизнедеятельности обусловлена интегративным характером самого предметного (ноксологического) знания и законами социально-экономического, социально-экологического и социально-педагогического развития.

В современных научных знаниях по предметной области БЖД доминируют интеграционные тенденции и проявляется междисциплинарный характер знаний по предметной области БЖД, которые включают в себя элементы ноксологических, биологических, экологических, физических, химических, технических, географических, медицинских, социологических, психологических, математических, военных и других наук.

В настоящее время значение интегративной функции предметной области БЖД возрастает также в связи с тем, что усиливается внимание к новым комплексным проблемам (синергетические природные катастрофы, международный терроризм, ядерная безопасность и др.), выявляется их реальная значимость. Интеграция в образовании в области БЖД в ВПО проявляется:

- в системности содержания образовательного пространства БЖД;

- во взаимосвязи и взаимодействии дисциплин специализации и дисциплин предметной подготовки с дисциплинами общепрофессионального, математического, естественнонаучного, гуманитарного и социально-экономического циклов;

- во взаимодействии предметной подготовки с психолого-педагогической и методической подготовкой;

- в интегрированности структурных компонентов методической системы подготовки специалистов образования в области безопасности жизнедеятельности;

- во взаимосвязи теоретической и практической предметной подготовки студентов, теории и практики методики обучения БЖД; 
- во взаимосвязи лекционных, практических, лабораторных, семинарских занятий, курсовых и дипломных работ и педагогических практик, студенческих научных конференций;

- в способности расширения профессиональной эрудиции специалиста образования в области безопасности жизнедеятельности и др. [1].

4. Единство обучения, воспитания и развития личности в подготовке специалиста образования в области БЖД.

Профессионализация личности специалиста образования в области БЖД в процессе образования представляет собой сложный, длительный и многоступенчатый процесс, связанный с усвоением уровней профессиональной деятельности (от репродуктивного до творчески-моделирующего). Овладение студентами на начальном этапе их обучения ноксологическими знаниями, знанием теоретических основ безопасности человека является фундаментом, на котором формируется образовательная функция будущего специалиста образования в области БЖД, его возможности и особенности трансляции этих знаний подрастающему поколению.

Развитие у студентов сознательного отношения к природной, техногенной, социальной среде, формирование культуры безопасности и определенных качеств личности безопасного типа поведения как её элементов, можно считать необходимой основой для проявления воспитательной и развивающей функции учителя безопасности жизнедеятельности. Учитель-предметник должен четко представлять себе место и роль образования в области БЖД как в мировом культурном движении, так и в становлении личности ученика.

Таким образом, образование в области безопасности жизнедеятельности имеет специфические показатели, такие как:

- образование в области безопасности жизнедеятельности выступает главенствующим элементом защиты объектов безопасности от воздействия комплекса негативных факторов окружающей его природной, техногенной и социальной среды;

- уникальность образования в области безопасности жизнедеятельности состоит в том, что оно по-новому ставит свои цели, сущностью которых являются формирование культуры безопасности жизнедеятельности, качеств личности безопасного типа поведения;

- образование в области безопасности жизнедеятельности по-новому подходит к содержанию образования, так как оно носит интегративных характер и требует овладения широким спектром комплексных межпредметных общенаучных и прикладных знаний; 
- прогностическая направленность образования в области безопасности жизнедеятельности, связанная с необходимостью распознавать, оценивать и прогнозировать опасности и угрозы, действующие на человека, природу, социум в условиях их непрерывного взаимодействия с техносферой;

- практико-ориентированная направленность образования в области безопасности жизнедеятельности, характеризующаяся внедрением профессионально-ориентированных технологий обучения, способствующих формированию у студентов значимых для будущей профессиональной деятельности качеств личности безопасного типа поведения, a также знаний, умений и навыков, обеспечивающих качественное выполнение функциональных обязанностей в выбранной профессиональной области;

- компетентностно-деятельностная направленность образования в области безопасности жизнедеятельности, способствующая подготовке специалиста, обладающего высоким уровнем профессионализма и компетентности, умеющего творчески находить, усваивать и пользоваться ноксологической информацией при анализе различных проблемных ситуаций в системе «человек - природа - общество - техносфера».

Представленные показатели показывают высокую и многостороннюю значимость образования в области безопасности жизнедеятельности и позволяют обеспечить практическую реализацию основополагающих принципов образования в данной научной области.

\section{Список литературы}

1. Абрамова С.В., Бояров Е.Н. и др. Реализация компетентностного подхода в структуре образовательного пространства «Безопасность жизнедеятельности» в условиях модернизации современного образования: Монография / Инновационные технологии в образовании: теория и практика. Книга 3. - Красноярск: Научно-инновационный центр, 2011. - С. 310-354.

2. Краевский В.В., Бережнова Е.В. Методология педагогики: новый этап: учеб. пособие для студ. высш. учеб. заведений. - М.: Издательский центр «Академия», 2006. 400 c. - C. 91.

3. Непрерывное педагогическое образование. Вып. XVI: Теоретические основы многоуровневого естественнонаучного педагогического образования: Коллективная монография. - СПб.: Изд-во РГПУ им. А.И. Герцена, 2002. - 205 с.

4. Теория и методика обучения безопасности жизнедеятельности: учеб. пособие для студ. высш. учеб. заведений / [Л.А. Михайлов, О.Н. Русак, В.П. Соломин и др.]; под ред. Л.А. Михайлова. - М.: Издательский центр «Академия», 2009. - 288 с. - С. 13-15.

5. Шершнев Л.И. Роль и место образовательной области БЖД в российском образовании // ОБЖ. Основы безопасности жизни.- 2008. - № 9. - С. 34, 38. 
Рецензенты:

Мисиков Б.Р., д.П.н., профессор, ректор Сахалинского государственного университета, ФГБОУ ВПО «Сахалинский государственный университет», г. ЮжноСахалинск.

Станкевич П.В., д.п.н., профессор, декан факультета безопасности жизнедеятельности, ФГБОУ ВПО «Российский государственный педагогический университет имени А.И. Герцена», г. Санкт-Петербург. 